\title{
TAGUNGSBERICHTE
}

\section{The Complexity of Pro-poor Agricultural Intensification} Report on the Workshop "Low-input Intensification of Agriculture - Chances and Barriers in Developing Countries"

Karlsruhe, December 8, 2010

\section{by Rolf Meyer, ITAS, and Dieter Burger, IfGG}

The KIT start-up project "Potentials of lowinput intensification in developing countries" 1 is focused on smallholders who represent the vast majority of farmers in developing countries. They play a key role to achieve increasing agricultural production and strong economic growth in agriculture, and therewith to reduce hunger and poverty in developing countries. At the same time, a more sustainable land use is urgently requested.

The project started from the hypothesis that - with the focus on small-scale farmers agricultural production systems like Conservation Agriculture, System of Rice Intensification, Organic Farming and Agroforestry Systems are candidates for higher food production and sustainable land utilisation in developing countries. These production systems have the potential for a "low-input intensification", especially meeting the needs and possibilities of small-scale farmers. They can be described as complex agricultural systems of intensification through higher agro-ecological and biological productivity. They do not necessarily require higher external inputs (as mineral fertilizer and pesticides). Instead, they focus on the optimisation of input utilisation. Improved management of soil and water are central elements.

In this context, the workshop on December 8, 2010 at the so-called "Fasanenschlösschen" in Karlsruhe aimed to discuss the potentials of low-input intensification and to identify adequate problem-oriented research approaches. ${ }^{2}$ In consideration of the complex issue, three perspectives were brought together in the workshop:
1. Global baselines: To assess the potentials for low-input intensification in the agriculture of developing countries, the geophysical and climatological situation on the one hand (Katharina Butz, IfGG) and the challenges for small-scale farming, the characteristics, distribution and hindrances of low-input agricultural production systems on the other hand (Rolf Meyer, ITAS) were presented, based on the work in the project. Both speakers came to the conclusion that overall assessments of potentials are only a first step and that locally adapted assessments and solutions are needed in the next step.

2. Case studies: Experiences with low-input intensification were presented for very different settings, regions and research approaches. Shilpi Saxena discussed the market channels for organic vegetable farmers in Tanzania and the constraints in their marketing chains to explore better marketing strategies for the small-scale farmers on the national market. The current situation of irrigation within the southern date palm oasis of Tunisia and potentials of irrigation efficiency improvement were analysed by Nizan Omrani (Institute of Arid Regions, Tunisia). Research results about the influence of soil micro-fauna on soil fertility were reported from a project in Central Amazonia, Brazil (Raphael Knoll and Dieter Burger, IfGG). Finally, Carsten Marohn (University of Hohenheim) gave an overview on Agroforestry Systems, and reported about the potentials of and constrains for agroforestry in the uplands of Thailand and Vietnam, including different modelling approaches.

The most important common lines were that the soil fertility is strongly endangered and low-input approaches have the potential to achieve significant increases in productivity. Additional points were: The influence of economic conditions - agricultural prices and high returns for specific crops - favours monocultures (date palms in Tunisia) or annual crops (uplands of Vietnam and Thailand) instead of Agroforestry Systems with multiple cultivars. Access to (and information about) regional, national and/or international markets can be an important bottleneck for the realisation of increased yields. Research activities often suffer from missing continuity and links to farmers so 
that research results contribute insufficiently to improved farming practices.

3. Development and research policy perspectives: In the last part, Stephan Krall (Deutsche Gesellschaft für Internationale Zusammenarbeit) presented research needs from the development assistance perspective, and Marc Dusseldorp (Office for Technology Assessment at the German Bundestag - TAB), based on the TAB-project "Research contributions to solving the world food problem", discussed the relevance of participatory research approaches for low-input intensification and options to reduce the existing constrains in the research funding and organisation.

The term "low-input intensification" was discussed controversially and alternatives such as sustainable intensification or eco-functional intensification were proposed. Agreement was reached that low-input intensification focuses on more independence from classical external inputs such as synthetic fertilizer and pesticides. It is in so far misleading as such external inputs are subsidized by higher demand for information, knowledge, networking, production system adjustments, etc. which are in most case "external" and associated with different kind of costs. This constitutes that low-input intensification normally happens not by itself but requires policy support.

\section{Notes}

1) The KIT start-up project is jointly carried out by the Institute for Technology Assessment and Systems Analysis (ITAS, Campus North) and the Institute for Geography and Geoecology (IfGG, Campus South).

2) The workshop proceedings will be published as KIT Scientific Report No. 7584.

\section{《》}

\section{Initiativen in der Climate- Engineering-Forschung Projekte, Konferenzen, Netzwerke: Ein Bericht über ausgewählte Forschungs- aktivitäten in Deutschland}

\section{von Stephanie Uther, Universität Heidelberg, und Nils Matzner, RWTH Aachen}

In den letzten Jahren hat in Deutschland die wissenschaftliche Beschäftigung mit den sog. Climate-Engineering- oder auch GeoengineeringTechnologien zunehmend an Bedeutung gewonnen. Bei Climate-Engineering-Technologien handelt es sich um Verfahren, die auf eine bewusste Beeinflussung des weltweiten Klimas durch technische Mittel zielen, um die negativen Folgen des Klimawandels abzumildern. ${ }^{1}$ Dabei lassen sich zwei Maßnahmengruppen unterteilen: Methoden des „Solar Radiation Managements“ (SRM) bewirken eine Veränderung der Strahlungsbilanz der Erde, indem sie die absorbierte Solarstrahlung reduzieren und dadurch einen kühlenden Effekt hervorrufen. Im Gegensatz dazu greifen „Carbon Dioxide Removal"-Maßnahmen (CDR) in den Kohlenstoffkreislauf der Erde ein, um die bestehende Menge an Treibhausgasen in der Erdatmosphäre zu verringern. Der folgende Bericht stellt überblicksartig ausgewählte Veranstaltungen aus der deutschen Climate-Engineering-Forschung vor. Der Beitrag soll dazu dienen, über zurückliegende, aktuelle und zukünftige Initiativen zu informieren, indem einzelne Konferenzen und Expertentagungen, Projekte und Forschungsnetzwerke besprochen werden.

\section{Forschungsprojekt „The Global Governance of Climate Engineering"}

Im Oktober 2009 startete am Marsilius-Kolleg der Universität Heidelberg das interdisziplinäre Forschungsprojekt „The Global Governance of Climate Engineering“, dessen Ziel es ist, die Chancen und Risiken unterschiedlicher ClimateEngineering-Technologien aus natur-, geistesund sozialwissenschaftlicher Forschungsperspektive kritisch zu untersuchen. ${ }^{2}$ Auf individueller, gesellschaftlicher und globaler Ebene sollen 